\title{
Contents
}

Important announcement

Imited paper

Sykes, A. R.

Parasitism and production in farm animals

Papers

Logue, D. N., Offer, J. E. and Hyslop, J. J.

Relationship of diet, hoof type and locomotion score with lesions of the sole and white line in dairy cattle

\section{Brotherstone, $\mathbf{S}$.}

Genetic and phenotypic correlations between linear type traits and production traits in HolsteinFriesian dairy cattle

Renaville, R., Massart, S., Lognay, G., Devolder, A., Sneyers, M., Marlier, M., Severin, M., Burny, A. and Portetelle, D.

Influence of a hormonal preparation containing glucocorticoids (dexamethosone esters), progestagen (chlormadinone acetate) and oestrogen (ethinyl oestradiol) on testosterone, insulinlike growth factor-1 (IGF-1), IGF-binding proteins and spermatogenic cells in finishing bulls

Keane, M. G.

Productivity and carcass composition of Friesian, Meuse-Rhine-Issel (MRI) $X$ Friesian and Belgian Blue $X$ Friesian steers

Kumar, U., Sareen, V. K. and Singh, S.

Effect of Sacharomyces cereisine yeast culture supplement on ruminal metabolism in buffalo calves given a high concentrate diet

Carro, M. D., Mantecón, A. R., Wright, I. A. and Gordon, I. J.

Effect of time of supplementary feeding on intake, apparent digestibility and rumen fermentation of grass hay by sheep

Oberbauer, A. M., Amold, A. M. and Thonney, M. L.

Genetically, size-scaled growth and composition of Dorset and Suffolk rams

Bonsi, M. L. K., Osuji, P. O., Nsahlai, I. V. and Tuah, A. K.

Graded levels of Seshania sesban and Lewcann leucociphala as supplements to teff straw given to Ethiopian Menz sheep

Wiener, G., Lee, G. J. and Woolliams, J. A.

Consequences of inbreeding for financial returns from sheep

Cameron, N. D.

Selection for components of efficient lean growth rate in pigs. 1. Selection pressure applied and direct responses in a Large White herd

Cameron, N. D. and Curran, M. K.

Selection for components of efficient lean growth rate in pigs. 2. Selection pressure applied and direct responses in a Landrace herd

Cameron, N. D., Curran, M. K. and Kerr, J. C.

Selection for components of efficient lean growth rate in pigs. 3. Responses to selection with a restricted feeding regime

Cameron, N. D. and Curran, M. K.

Selection for components of efficient lean growth rate in pigs. 4. Genetic and phenotypic parameter estimates and correlated responses in performance test traits with ad-libitum feeding

Everts, H. and Dekker, R. A.

Effect of nitrogen supply on the retention and excretion of nitrogen and on energy metabolism of pregnant sows

Patón, D., Cardona, L. and Gisbert, E.

Comparative growth in relation with the age assessed by skeletochronology in two nullet fishes of genus Liza

Cilliers, S. C., Hayes, J. P., Maritz, J. S., Chwalibog, A. and Preez, J. J. du

True and apparent metabolizable energy values of lucerne and yellow maize in adult roosters and mature ostriches (Struthio camelus)

Nofes:

Davis, M. E. and Bishop, M. D.

A note on consequences of single-trait selection for insulin-like growth factor-1 (IGF-1) in beef heifers 